\title{
Effects of Atractyloside on the Incorporation of Radioactive Precursors into DNA in Isolated Rat Liver Mitochondria'
}

\author{
R. S. MITRA AND I. A. BERNSTEIN \\ Departments of Environmental and Industrial Health, Dermatology and Biological Chemistry, \\ The University of Michigan Medical Center, Ann Arbor, Michigan 48104 \\ Received July 10, 1970; accepted September 22, 1970
}

\begin{abstract}
Atractyloside $(20 \mu \mathrm{M})$ has been found to decrease the ineorporation of dATP- ${ }^{3} \mathrm{H}$ into DNA by $90 \%$ in intact mitochondria (at a level of $3 \mathrm{mg}$ of protein) but to have no such effect on sonic extracts of mitochondria nor on the DNA polymerase from Escherichia coli. Inhibition of $\mathrm{dATP}-{ }^{-3} \mathrm{H}$ incorporation by atractyloside can be overcome by increasing the level of ATP present. The incorporation of TTP ${ }^{3} \mathrm{H}$ is not similarly inhibited by atractyloside. TTP- ${ }^{3} \mathrm{H}$ incorporation, which is stimulated by added ATP, is inhibited by atractyloside to the extent of $40 \%$ in the absence of and $13 \%$ in the presence of ATP ( $2 \mathrm{mM}$ ). Atractyloside can be used with labeled dATP to ascertain that DNA synthesis is occurring intramitochondrially in intact organelles, in vitro, rather than externally as a result of contaminating nuclear DNA polymerase.
\end{abstract}

A previous study (1) of the incorporation of thymidine $-{ }^{3} \mathrm{H}$ into mitochondrial DNA, in vitro, required the demonstration that DNA synthesis was indeed intramitochondrial and was not merely a result of contaminating nuclear DNA polymerase in our preparation. It occurred to us that atractyloside, a compound which appears to bind to the inner mitochondrial membrane (2) and to abolish the entry of external adenine ribonucleotides into intact mitochondria (3), might be useful in confirming that DNA was synthesized inside the organelle in our experiments. This substance has been used to demonstrate the existence of an active RNA polymerase inside the mitochondria and the conversion of labeled ATP into RNA therein (4). Atractyloside does not appear to affect the transport of adenine ribonucleotides into intact nuclei (4).

This paper presents data which indicate that atractyloside prevents the incorpora-

1 This work has been supported by Research Grant G23740 from the National Science Foundation and Research Grants 5 SO1 FR 05447 (GRS) and 2 RO1 AM 03429 from the National Institutes of Health. tion, in vilro, of $\mathrm{dATP}^{-3} \mathrm{H}$ into mitochondrial DNA in the intact organelle but not in a disrupted preparation. These observations support the previous conclusion (1) that intact mitochondria were used to demonstrate the incorporation of thymidine $-{ }^{3} \mathbf{H}$ into DNA in vitro. It appears that atractyloside and labeled dATP would be useful in ascertaining the degree of intactness of isolated mitochondria.

\section{MATERIALS AND METHODS}

Deoxyadenosine-5'-triphosphate- $8-{ }^{3} \mathrm{H} \quad(3.8 \mathrm{Ci} /$ mmole) and thymidine-5'-triphosphate- ${ }^{3} \mathrm{H}(4.0 \mathrm{Ci} /$ mmole) were purchased from Schwarz Bioresearch Inc. Chemicals were obtained from previously mentioned sources (1). Atractyloside was a gift from Dr. A. Bruni.

Isolation of mitochondria from rat liver and biochemical activities and electron microscopic studies of the isolated mitochondria have been previously described (1).

Preparation of sonic extracts of mitochondria. Isolated mitochondria were suspended in $0.1 \mathrm{M}$ Tris-chloride buffer ( $\mathrm{pH} 8.0$ ), (approximately 10 $\mathrm{mg}$ protein $/ \mathrm{ml}$ ) and subjected to sonication for $30 \mathrm{sec}$ (Raytheon Sonic Oscillator, Model DF 101) four times in the cold. The suspension was well cooled between each sonication. The suspension 
was then centrifuged at $15,000 \mathrm{~g}$ for $10 \mathrm{~min}$ at $2^{\circ}$, and the supernatant fraction was used for the incorporation studies.

Mitochondria or sonic extracts of mitochondria were incubated in a system slightly modified from that used by Parsons and Simpson (5). The medium contained the following reagents: $0.34 \mu \mathrm{M}$ dATP- ${ }^{3} \mathrm{H}$ and $0.02 \mathrm{mM}$ TTP or $0.34 \mu \mathrm{M}$ TTP- ${ }^{3} \mathrm{H}$ and $0.02 \mathrm{~mm}$ dATP plus $0.02 \mathrm{~mm}$ dGTP, $0.02 \mathrm{~mm}$ dCTP, $2.0 \mathrm{~mm}$ ATP, $10.0 \mathrm{~mm}$ succinate, $2.0 \mathrm{~mm}$ pyruvate, $1.0 \mathrm{~mm}$ malate, $2.0 \mathrm{~mm}$ nicotinic acid (potassium

TABLE I

REQUIREMENTS FOR TTP-3H INCORPORATION in Isolated Rat Liver Mitochondria ${ }^{a}$

\begin{tabular}{lc}
\hline \multicolumn{1}{c}{ System } & $\begin{array}{c}\mu \mu \text { moles TTP-3H } \\
\text { incorporated/hr/10 } \\
\text { mg protein }\end{array}$ \\
\hline Complete & 1.20 \\
minus ATP & 0.72 \\
minus dATP, dGTP and dCTP & 0.68 \\
minus dATP & 0.79 \\
minus dGTP & 0.51 \\
minus dCTP & 0.75 \\
minus succinate, pyruvate, & 0.84 \\
malate, nicotinic acid $(\mathrm{K}$ salt), & \\
KCl, and KH${ }_{2} \mathrm{KO}_{4}$ &. \\
\hline
\end{tabular}

a The complete system with TTP- ${ }^{3} \mathrm{H}$ has been described in the text. Reaction was carried out at $37^{\circ}$ for $1 \mathrm{hr}$ in a total volume of $1 \mathrm{ml}$. Mitochondrial protein was $3.1 \mathrm{mg}$. Radioactivity was measured in acid-insoluble material. salt), $10.0 \mathrm{mM} \mathrm{MgCl}_{2}, 2.0 \mathrm{mM} \mathrm{KCl}, 10.0 \mathrm{mM} \mathrm{KH}_{2}$ $\mathrm{PO}_{4}$, and $25.0 \mathrm{~mm}$ Tris ( $\mathrm{pH} 8.0$ ) in a total volume of $1.0 \mathrm{ml}$. The incubations were performed at $37^{\circ}$ without shaking. After the desired period of incubation, the reaction mixture was chilled, and the reaction was stopped by addition of $0.5 \mathrm{ml}$ of cold $0.1 \mathrm{M}$ sodium pyrophosphate and $1.0 \mathrm{ml}$ of cold $1.0 \mathrm{~N}$ perchloric acid (6). The radioactivity in the acid-insoluble material was determined after processing according to the method of Lehman (7). Finally, the acid-insoluble material was dis-

TABLE II

REQUIREMENTS FOR dATP-i ${ }^{-} \mathrm{H}$ INCORPORATION IN IsOLATED RAT LIVER MitochONDRIA ${ }^{a}$

\begin{tabular}{lc}
\hline \multicolumn{1}{c}{ System } & $\begin{array}{c}\mu_{\mu \text { moles dATP }} \\
\text { incorporated } \\
\text { mg protein } / 10\end{array}$ \\
\hline Complete & 3.85 \\
plus ATP (2.0 mM) & 2.62 \\
minus TTP, dGTP and dCTP & 2.75 \\
minus TTP & 2.83 \\
minus dGTP & 2.55 \\
minus dCTP & 2.90 \\
minus succinate, pyruvate, & 3.05 \\
malate, nicotinic acid (Ksalt), & \\
KCl, and KH $\mathrm{PO}_{4}$ &
\end{tabular}

a The complete system with $\mathrm{dATP}-{ }^{3} \mathrm{H}$ (minus ATP) has been described in the text. Reaction was carried out at $37^{\circ}$ for $1 \mathrm{hr}$ in a total volume of 1 $\mathrm{ml}$. Mitochondrial protein was $3.7 \mathrm{mg}$. Radioactivity was measured in acid-insoluble material.

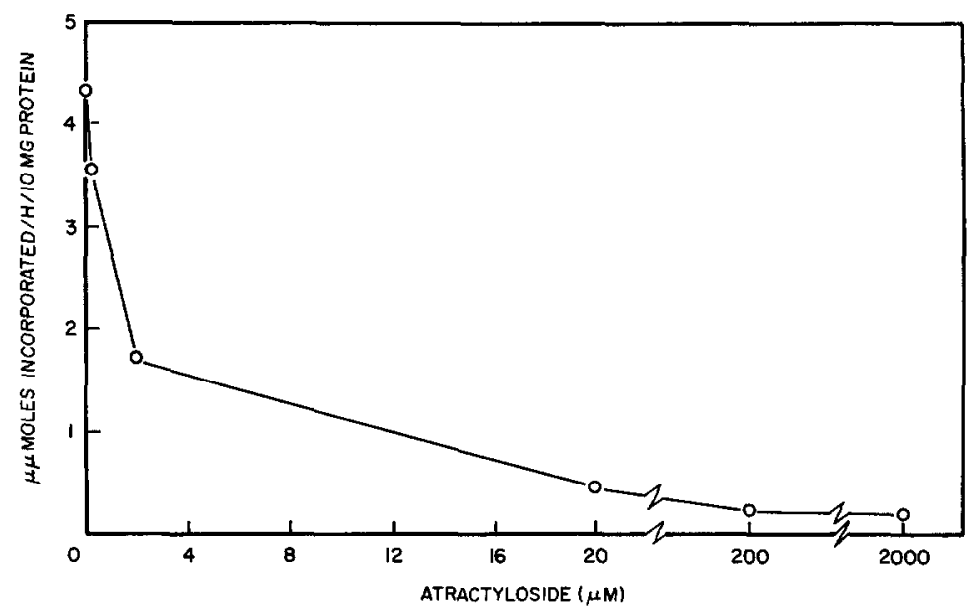

FIG. 1. Effect of atractyloside on the incorporation of dATP- ${ }^{3} \mathrm{H}$ into acid-insoluble material. Isolated mitochondria ( $3.0 \mathrm{mg}$ protein) were incubated in the presence or absence of atractyloside in the complete system (described in the text) containing dATP ${ }^{3} \mathrm{H}$ (minus ATP) for $1 \mathrm{hr}$ at $37^{\circ} \mathrm{in}$ a total reaction volume of $1 \mathrm{ml}$. Radioactivity was measured in the acid-insoluble material. 


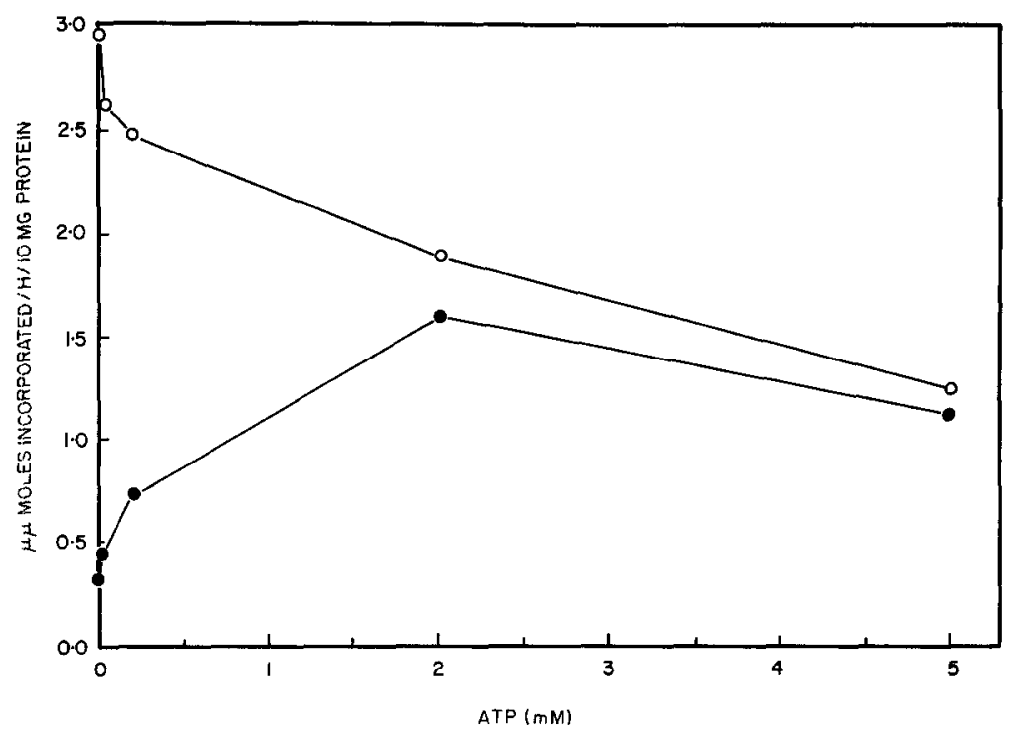

Fir. 2. Fffect of ATP on the incorporation of dATP- ${ }^{3} \mathrm{H}$ into acid-insoluble material in the presence or absence of atractyloside. Isolated mitochondria (2.8 $\mathrm{mg}$ protein) were incubated in the presence of atractyloside $(20 \mu \mathrm{M})\left(-\mathrm{O}_{-}-\right)$or in its absence $\left(-\mathrm{O}_{-} \mathrm{O}^{-} \mathrm{O}_{-}\right)$ in the complete system with AATP-$^{3} \mathrm{H}$ (described in the text) and varinus concentrations of ATP. The reaction was carried out for $1 \mathrm{hr}$ at $37^{\circ}$ in a total reaction volume of $1 \mathrm{ml}$. Radioactivity was measured in the acid-insoluble material.

solved in $\mathrm{NaOH}$, diluted with water, and counted in a liquid-scintillation counter using a scintillation mixture as previously described (1). In a few experiments, the acid-insoluble material was further treated with alcohol, alcohol-ether $(3: 1)$ and ether, but no significant difference was noted in the level of incorporation. Acid-denatured mitochondria were incubated under identical conditions as controls.

Protein was determined by the method of Lowry et al. (8).

\section{RESULTS}

The incorporation process is partially dependent on the presence of the four deoxyribonucleotides. Omission of succinate, malate, nicotinic acid (potassium salt), $\mathrm{KCl}$ and $\mathrm{KH}_{2} \mathrm{PO}_{4}$ from the complete system lowered the incorporation by $20-30 \%$. No specific attempt was made to study the effect of each component on the incorporation process. From Table I it is evident that the incorporation of labeled TTP when studied with intact mitochondria shows a requirement for ATP, the absence of which results in a $40-45 \%$ lower incorporation. On the contrary, ATP inhibits the incorporation of labeled dATP by $30-35 \%$ (Table II).
The effect of different concentrations of atractyloside on the incorporation of labeled dATP into acid-insoluble material is shown in Fig. 1. Inhibition of the incorporation to the extent of $90 \%$ occurs in the presence of atractyloside at a concentration of $20 \mu \mathrm{M}$ (mitochondrial protein $3.0 \mathrm{mg}$ ). No inhibition is observed at a concentration of $0.2 \mu \mathrm{M}$ or lower. The inhibition caused by atractyloside can be overcome by increasing the level of ATP. The inhibition, resulting from 20 $\mu \mathrm{M}$ atractyloside, is decreased from $95 \%$ to $50 \%$ upon raising the concentration of ATP from 2.0 to $5.0 \mu \mathrm{M}$ (Fig. 2).

The incorporation of labeled TTP into acid-insoluble material is inhibited by $20 \mu \mathrm{M}$ atractyloside to the extent of $40 \%$ in the absence and $13 \%$ in the presence of $2 \mathrm{~mm}$ ATP (Fig. 3). Raising the atractyloside concentration to $2 \mathrm{~mm}$ results in a minor increase in inhibition.

Table III shows the incorporation of labeled dATP or TTP into acid-insoluble material not to be inhibited by atractyloside in sonic extracts of mitochondria. Though the level of incorporation was low with the extract as compared to the intact mitochon- 


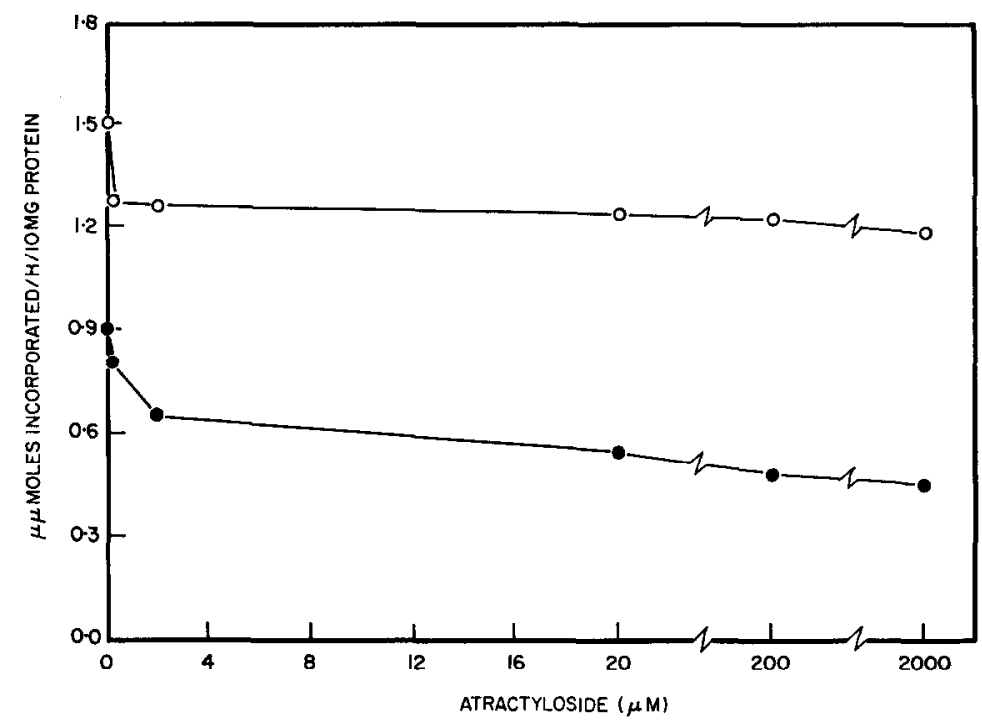

FIG. 3. Effect of atractyloside on the incorporation of TTP- ${ }^{3} \mathrm{H}$ into acid-insoluble material. Isolated mitochondria $(2.9 \mathrm{mg}$ protein) were incubated in the presence or absence of atractyloside in the complete system with TTP- ${ }^{3} \mathrm{H}$ (described in the text) (-O-O-O-) or complete system minus ATP (--) for $1 \mathrm{hr}$ at $37^{\circ}$ in a total reaction volume of $1 \mathrm{ml}$. Radioactivity was measured in the acid-insoluble material.

TABLE III

INCORPORATION OF dATP-3 ${ }^{3}$ OR TTP-s H INTO Acid-Insoluble Material by Sonic Extracts of Isolated Rat Liver Mitochondria ${ }^{a}$

\begin{tabular}{|c|c|c|c|c|}
\hline & \multicolumn{2}{|c|}{$\begin{array}{c}\text { Incubated with } \\
\text { dATP-3H ( } \mu \mu \text { moles } \\
\text { incorporated/hr/10 } \\
\text { mg protein) }\end{array}$} & \multicolumn{2}{|c|}{$\begin{array}{c}\text { Incubated with } \\
\text { TTP-3H (ummoles } \\
\text { incorporated/hr/10 } \\
\text { mg protein) }\end{array}$} \\
\hline & $\begin{array}{c}\text { Com- } \\
\text { plete } \\
\text { system }\end{array}$ & $\begin{array}{l}\text { Complete } \\
\text { system } \\
- \text { ATP }\end{array}$ & $\begin{array}{c}\text { Com- } \\
\text { plete } \\
\text { system }\end{array}$ & $\begin{array}{l}\text { Complete } \\
\text { system } \\
\text {-ATP }\end{array}$ \\
\hline $\begin{array}{l}\text { Control } \\
\text { plus atractylo- } \\
\text { side }(\mathrm{AT})\end{array}$ & 0.26 & 0.08 & 0.34 & 0.21 \\
\hline $\begin{array}{l}2 \times 10^{-7} \mathrm{M} \\
\text { plus AT }\end{array}$ & 0.24 & 0.07 & 0.34 & 0.25 \\
\hline $\begin{array}{l}2 \times 10^{-6} \mathrm{M} \\
\text { plus AT }\end{array}$ & 0.22 & 0.08 & 0.38 & 0.21 \\
\hline $\begin{array}{l}2 \times 10^{-5} \mathrm{M} \\
\text { plus AT }\end{array}$ & 0.24 & 0.08 & 0.34 & 0.26 \\
\hline $\begin{array}{l}2 \times 10^{-4} \mathrm{M} \\
\text { plus AT }\end{array}$ & 0.27 & 0.09 & 0.41 & 0.21 \\
\hline $2 \times 10^{-3} \mathrm{M}$ & 0.32 & 0.12 & 0.56 & 0.26 \\
\hline
\end{tabular}

a The complete system has been described in the text. The reaction was carried out at $37^{\circ}$ for $1 \mathrm{hr}$ in a total volume of $1 \mathrm{ml}$. The sonic extracts contained $2.1 \mathrm{mg}$ protein. Radioactivity was measured in acid-insoluble material.
TABLE IV

EFfect of Atractylostde on the Incorporation of dATP- ${ }^{3} \mathrm{H}$ into Acid-Insoluble Material BY DNA POLYMERASE FROM Escherichia $\operatorname{coli}^{\alpha}$

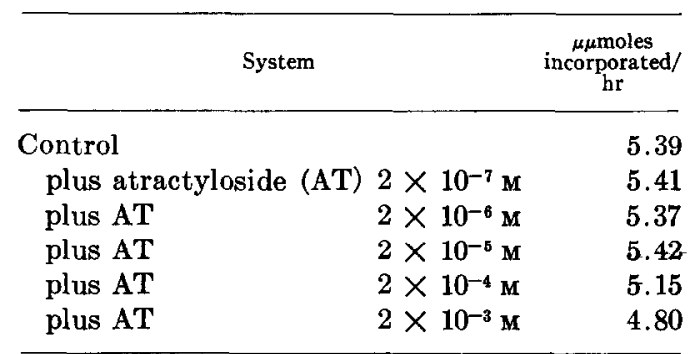

${ }^{a}$ E. coli DNA polymerase ( $\left.15 \mu \mathrm{g}\right)$ was incubated in the presence or absence of atractyloside in the complete system (described in the text) plus 5.0 $\mu \mathrm{g}$ of calf thymus DNA. dATP- ${ }^{3} \mathrm{H}(0.026 \mathrm{~mm})$ was used in this experiment. Incubation was carried out at $37^{\circ}$ for $1 \mathrm{hr}$ in a total reaction volume of $1 \mathrm{ml}$. The radioactivity precipitable by cold perchloric acid (after addition of $0.5 \mathrm{mg}$ calf thymus DNA) was then measured.

dria, the results were reproducible and consistent. For the incorporation of both the labeled substrates, ATP stimulated the process. It appears from Table III that 
atractyloside at higher concentrations stimulates the incorporation process when ATP is present.

Table IV demonstrates that up to $2 \times$ $10^{-5} \mathrm{M}$ atractyloside has no significant effect on the DNA polymerase from $E$. coli. A concentration of $2 \times 10^{-3} \mathrm{M}$ results in only a $10 \%$ inhibition.

\section{DISCUSSION}

Workers in several laboratories have demonstrated that isolated mitochondria from rat liver (5), yeast (9), and the mold, Physarum polycephalum (10) can incorporate deoxyribonucleotides into mitochondrial DNA. However, in studying DNA synthesis in isolated mitochondria, a major problem is to distinguish between true intramitochondrial synthesis and the synthetic activity of contaminating nuclear DNA polymerase. Use of atractyloside provides one means of solving this dilemma. The atractylosidesensitive mitochondrial carrier system (3) is apparently not specific for the ribonucleotides of adenine but also deals with the deoxyribonucleotides. Thus, the translocation of dATP as well as ATP is inhibited in intact organclles and labeled $\mathrm{d} \Lambda \mathrm{TP}$ is not incorporated into mitochondrial DNA. On the other hand, atractyloside does not inhibit this process in sonic extracts of the organelle nor is DNA polymerase of Escherichia coli significantly inhibited by this substance. This property of atractyloside makes it possible to explore with labeled dATP whether the formation of DNA occurs inside the mitochondria or is a function of contaminating DNA polymerase activity external to the mitochondria. $\mathrm{By}$ this criterion, more than $90 \%$ of the DNA was synthesized within the mitochondria in the present study.

In the experiments reported in this paper, we have measured the radioactivity in acidinsoluble material. Evidence that this material was DNA has been previously reported (1).

It has been observed that in order to achieve maximum incorporation of TTP- ${ }^{3}$ II in intact mitochondria, ATP is necessary (Table I) while in the case of $\mathrm{dATP}^{3} \mathrm{H}$ in- corporation, the addition of ATP lowers the incorporation (Table II). This phenomenon is difficult to explain. In sonic extracts the addition of ATP stimulated the incorporation of both $\mathrm{dATP}{ }^{3} \mathrm{H}$ and TTP- ${ }^{3} \mathrm{H}$ (Table III). A similar type of stimulation by ATP was observed by Meyer and Simpson (11) with their mitochondrial DNA polymerase fraction I (Mt-I). They suggested that the requirement for ATP in the Mt-I fraction resulted from the need to regenerate with ATP the enzymatically degraded precursors of DNA-especially GTP. Their purified mitochondrial DNA polymerase, however, did not require ATP for the incorporation of labeled deoxytriphosphates into DNA as is true, of course, with the DNA polymerase from $E$. coli.

Atractyloside has been found to strongly inhibit the incorporation of $\mathrm{dATP}^{3} \mathrm{H}$ (Fig. 1). This inhibition was partially reversed by addition of ATP (Fig. 2). Since andition of ATP decreased the incorporation of dATP ${ }^{3} \mathrm{H}$, it is not surprising that complete reversal of the inhibition by atractyloside was not achieved.

When the effect of atractyloside on the incorporation of $\mathrm{TTP}^{-}{ }^{3} \mathrm{H}$ was studied in the presence of the amount of ATP necessary to obtain maximal radioactive DNA, very little inhibition (about 13\%) was obtained (Fig. 3). A larger inhibition (about 40\%) was seen (Fig. 3) in the absence of ATP. These cffects presumably are a function of the effects of atractyloside on the transport of ATP and dATP into the mitochondria since these elements are necessary for the maximal incorporation of $\mathrm{TTP}-{ }^{3} \mathrm{H}$ into the DNA.

Although the incorporation of $\mathrm{dATP}_{-}{ }^{3} \mathrm{H}$ and TTP- ${ }^{3} \mathrm{H}$ into DNA in mitochondrial extracts prepared by sonication was low, it is clearly evident that atractyloside exerted no inhibition on the reaction (Table III). At a concentration of $2 \times 10^{-4} \mathrm{M}$, atractyloside inhibited the incorporation of dATP into intact mitochondrial DNA to the extent of $94 \%$ (Fig. 1) whereas, in the extracts the inhibition was negligible if it occurred at all (Table III). With TTP- ${ }^{3} \mathrm{H}$, even the low degree of inhibition seen in intact mitochondria was not observed in the extracts. 
The stimulation of incorporation of both labeled precursors noted in extracts at higher concentrations of atractyloside, may have been a result of inhibition of ATPase since the incorporation was stimulated by ATP (Table III) but the effect was not further studied.

The low level of incorporation of labeled dATP and TTP into DNA in the extracts may have been a result of destruction of the catalytic system or of primer DNA during the sonication. Attempts to increase the level of incorporation by adding mercaptoethanol to the complete system or by preparing the extract according to the method of Kalf and Ch'ih (12) were unsuccessful. Since the activity obtained was sufficient to show that atractyloside had no inhibitory effect, no further efforts in this direction were made.

\section{ACKNOWLEDGMENTS}

The authors thank Dr. A. Bruni, Institute of Pharmacology, University of Padua, Italy, for the kind gift of atractyloside.

\section{REFERENCES}

1. Mrtra, R. S., and Bernstein, I. A., J. Biol. Chem. 245, 1255 (1970).

2. Vignais, P. V., and Vignais, P. M., Biochem. Biophys. Res. Commun. 38, 843 (1970).

3. Winkler, H. H., Bygrave, F. L., ANd LehNINGER, A. L., J. Biol. Chem. 243, 20 (1968).

4. Saccone, C., Gadaleta, M. N., and Quagliariello, E., Biochim. Biophys. Acta 138, 474 (1967).

5. Pansons, P., And Simpson, M. V., Science 155, 91 (1967).

6. Spencer, D., and Whitfeld, P. R., Biochem. Biophys. Res. Commun. 28, 538 (1967).

7. LmhmaN, I. R., in "Methods in Enzymology" (S. P. Colowick and N. O. Kaplan, eds.), p. 35. Academic Press, New York (1963).

8. Lowry, O. H., Rosebrough, N. J., Farr, A. L., ANd Randall, R. J., J. Biol. Chem. 193. 265 (1951).

9. Wintersberger, E., Biochem. Biophys. Res. Commun. 25, 1 (1966).

10. Brewer, E. N., Devries, A., and Rusch, H. P., Biochim. Biophys. Acta 145, 686 (1967).

11. Meyer, R. R., and Simpson, M. V., Prac Nat. Acad. Sci. U. S. A. 61, 130 (1968).

12. Kalf, G. F., ANd Ch'IH, J. J., J. Biol Chem. 243, 4904 (1968). 